вмотивованості студентів до навчальної діяльності; 4) створення спільноти у соціальній мережі за допомогою cервісу Google+; 5) проведення відео-конференцій з іншими студентам за допомогою Google Hangouts. Для активізації самостійності студентів під час виконання завдань за допомогою хмарних технологій були використані наступні методи: метод формування свідомості, метод збору та реєстрації інформації, метод «зворотний зв'язок». Показано, що застосування хмарних технологій Google Apps у процесі навчання сприяє створенню стійкої мотивації студентів до оволодіння усним професійним мовленням та активізації самостійності під час навчання. Констатовано, що Інтернет-додаток Google Apps та його хмарні сервіси, що у нього входять, можуть допомогти студентам факультету хореографічної освіти більш ефективно опановувати навички англійського професійного мовлення.

Ключові слова: інтерактивність, хмарні технології, усне мовлення, самостійність, активізація.

Reviewed by Doctor of Pedagogy, prof. T. Yablonska

Submitted on March, 16, 2017

UDC: 378:373.2:004

DOI: https://doi.org/10.24195/2414-4665-2017-4-10

\author{
Oksana Chekan, \\ PhD (Candidate of Pedagogical Sciences), senior lecturer, \\ Khrystyna Barna, \\ PhD (Candidate of Pedagogical Sciences), senior lecturer, \\ Viktoriia Ivanova, \\ PhD (Candidate of Psychological Sciences), senior lecturer, \\ Department of Theory and Methodology of Preschool Education, \\ Mukachevo State University, \\ 26, Uzhhorodska Str., Mukachevo, Ukraine
}

\title{
FORMATION OF FUTURE NURSERY TEACHERS' PROFESSIONAL COMPETENCE BY MEANS OF INFORMATION AND COMMUNICATIONS TECHNOLOGIES
}

The article deals with the stages of future nursery teachers' professional competence formation by means of information and communications technologies. Future nursery teachers' readiness to use information and communications technologies in their work is an integrated indicator which is manifested in stable associative bonds between professional competencies and models of their realization with the use of information and communications technologies; in acquiring information and communication technologies which are essential for effective fulfillment of basic functional operations in the information environment of a modern preschool educational institution; in the ability to interpret all tasks of educational and commutative processes of a preschool institution through available functional components of external and internal information environments. The following stages of future nursery teachers' professional competence formation by means of information and communications technologies have been distinguished: cognitive and enriching, productive and active, creative and informational. The formation of future nursery teachers' professional competence based on the application of information and communications technologies together with the use of microteaching methodology for the formation of associative connections can be assessed according to the following criteria: cognitive-informational, activity-informational, managerial-informational.

Keywords: information and communications technology, professional competence, computer-oriented technology.

\section{Introduction}

The task of higher education in the period of society informatization is the training of professionals able to use modern innovative technologies at the necessary level. According to the Law of Ukraine "On Education", the purpose of education is comprehensive development of a personality as the greatest value of the society, development of person's talents, mental and physical abilities, education of high moral qualities, formation of citizens able for conscious social selection, enrichment of intellectual, creative and cultural potential of nation on this basis, increasing of educational level, providing of national economy with qualified specialists.

The term "information and communication technologies" is increasingly spreading in modern science and education. Its variants "modern information tech- 
nologies", "computer technologies", "innovative technologies in education" are used in psychology and education with variable formulations depending on the way authors understand the structure and components of the educational process (N. Apatova, V. Hlushkov, O. Bohatyrova, A. Koptielov, H. Nekrasov, O. Tebiieva, V. Sholokhovych, H. Bordovskyi, V. Izvozchikov, A. Dziubenko, V. Morozov, M. Zhaldak, O. Semenoh, A. Matiushkin, M. Averyna, H. Chystiakova, V. Khymynets and others).

Some scientists associate the optimization of the educational process with the use of ICT (K. Boikachev, V. Venda, R. Herhei, B. Gershunskiy, B. Lom, V. Lyaudis, E. Malinochka, E. Mashbits, A. Savelev, G. Selevko and others).

Domestic experience of using ICT in the sphere of education is described in the works of A. Barabanshchikov, V. Bespalko, Ya. Vagramenko, T. Voronin, Yu. Demin, V. Dyk, V. Ivanov, M. Karpenko, D. Kolosov, S. Kramarov, A. Krivosheyev, S. Lobachev, N. Makarova, V. Matiukhin, O. Molchanova, V. Ovsiannykov, A. Poliakov, Yu. Popov, A. Savelev, V. Samoilov, B. Soldatkyn, A. Tikhonov, S. Shchennykov, A. Fedoseiev, A. Khoroshylov and others.

The paper aims to analyze the stages of future nursery teachers' professional competence formation by means of ICT.

\section{Discussion}

There are a great number of higher educational establishments in our country which provide the training of future nursery teachers, though the curricula in the institutions are different, especially in the number of hours of computer science courses. The state and higher educational establishments have to provide preschool institutions with "informationally competent" educators in the field of computer technology for the full development of preschoolers in the contemporary society.

What is an "informationally competent" educator in the field of computer technology? It should be noted that the majority of dictionaries provide the definition of the words "competence" and "competent" in the following way: one that has sufficient knowledge in some field, is well acquainted with something, and is qualified; the one who has competency [6, p. 555-560].

The word "competence" originates from the Latin word "competentio", which in its turn originates from the word "compete" (literally: to achieve, to fit). The dictionary of foreign words defines this notion as enlightenment, familiarity, authority [6, p. 568-570].

Thus, it is a personality who not just has skills of working with a computer but also skills to apply and to use it during work with preschool children.

Due to the fact that one of the tasks of this research is distinguishing groups of parametric criteria for diagnosing students' readiness to the use of information and communications technologies in their future work, the term "criterion" should be explained. We understand it as the "basis for assessing something" [6, p.380-382]; as "characteristics on basis of which something is evaluated; conditionally adopted measure which helps to measure an object and to assess it on this basis" [6, p. 271-272].

The term "information and communications technologies" was initially implemented into scientific usage by V. Hlushkov, who defined information and communications technology as the processes connected with information readjustment [3, p. 458-459].

N. Apatova concretized it in the following way: "Information technology is a set of means and methods with the help of which the process of information readjustment is fulfilled" [1, p. 22-29].

We understand professional competence of future nursery teachers formed by means of computer technology as a result of general and professional education which allows them to use information and communication technologies with the purpose of effective use of informatics content of preschool institution and resources of open information environment, to support contemporary system of communication with parents and colleagues, to expand the level of professional competence through the use of Internet technology, to support implementation of information technology into preschool institution's management system.

Competence is result-acting characteristic of education. Professional competence of a nursery teacher is formed in empirical way as generalized characteristic of educational activity in the process of purposeful studying in higher educational establishment.

According to $\mathrm{H}$. Bielienka, the main stages of nursery teacher's professional competence formation under conditions of studying are as follows: adaptive and orientational, meaningful and reflexive, practical and transformational [2, p. 150-156]. H. Bielienka defines structure of nursery teacher's professional competence "as a combination of the following interrelated components: personal, meaningful and processual, reflexive and evaluative, creative" [2, p. 158-162].

Thus, future nursery teachers' readiness to use information and communications technologies in their work is an integrated indicator which is manifested in the availability of stable associative bonds between professional competencies and models of their realization with the use of information and communications technologies; in acquiring information and communication technologies which are essential for effective fulfillment of basic functional operations in the information environment of a modern preschool educational institution; in the ability to interpret all tasks of educational and commutative processes of a preschool institution through available functional components of external and internal information environments.

According to the aim of the research on the basis of the theoretical analysis the following stages of future nursery teachers' professional competence formation by means of information and communications technologies have been distinguished (fig. 1): cognitive and enriching 
stage, productive and active stage, creative and informational stage.

The training process provided to teach future nursery teachers:

- to understand the principles of a specific computer technology;

- to know the main components of modern computer equipment;

- to have skills for managing main functions of operating system which is used by them;

- to estimate software and hardware with the purpose of its use in the educational process of a preschool educational institution;

- to use various peripheral equipment;

- to learn the principles of construction of modeling and simulation systems;

- to learn software for educational material which is designed for children of preschool age;

- to be able to find necessary information in Internet, to store and to use it;

- to use computer technology for making connections with parents, colleagues etc.;
- to use multimedia tools for preparation of educational lessons in preschool institutions;

— to be able to detect what software is needed for the preparation of their own teaching materials for further professional activity;

- to know classification of software intended for use in the educational process of a preschool institution;

- to be able to assess advantages and disadvantages of the use of computer technology in work with children;

- to identify and to evaluate informatics tools which may be available for parents and children;

- to identify software which is used in the educational process of a preschool institution;

- to develop lessons with the use of computer technologies (method of individual studying, studentcentered education, etc.);

— to be able to use computer technologies to work with parents.

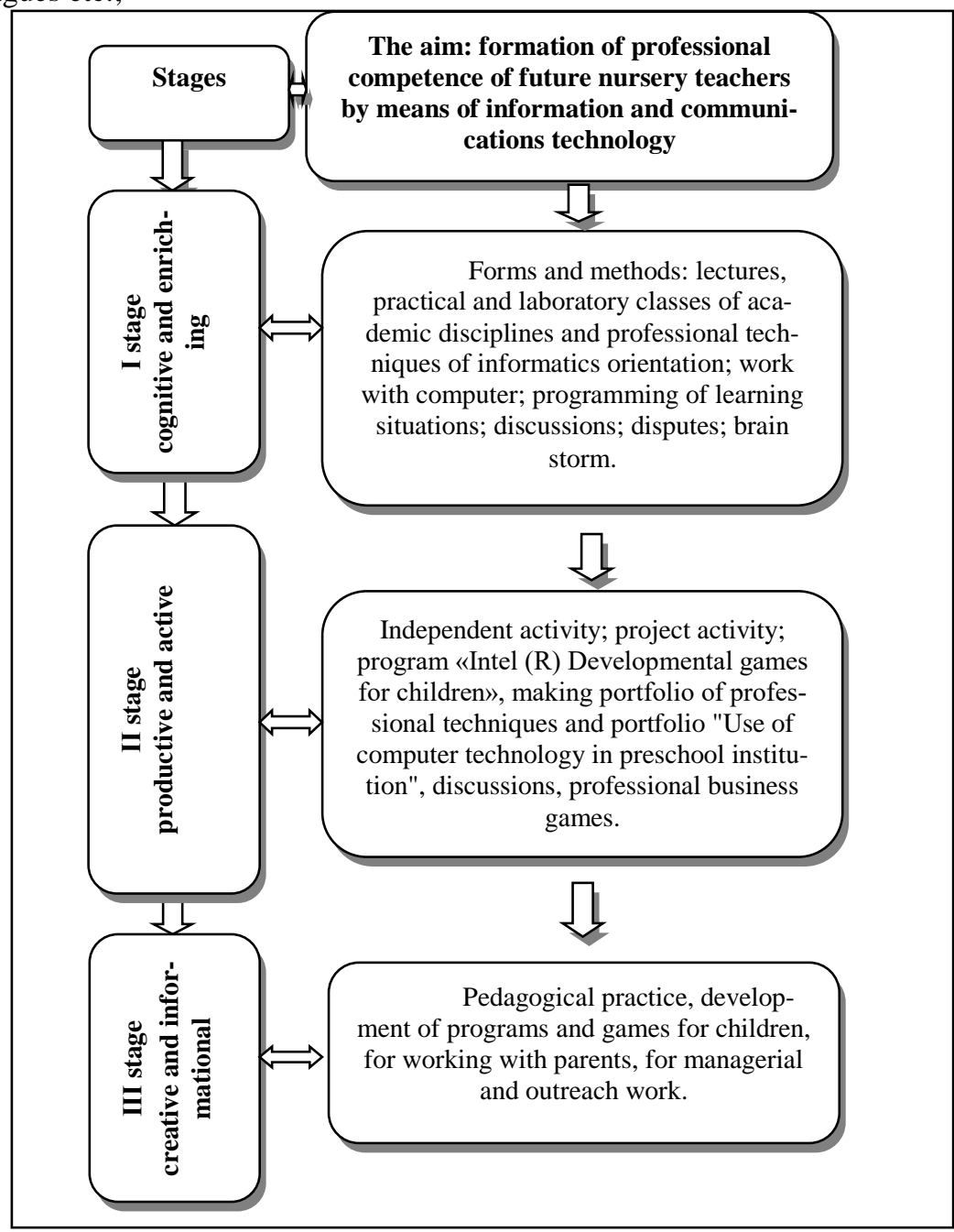

Fig. 1. Stages of future nursery teachers' professional competence formation by means of information and communications technologies 
The presented stages of future nursery teachers' professional competence formation by means of information and communications technologies provide the educational process participants' adequate respond to the informatics requests of child's social environment. Information and communications technologies integrated into the teaching methodology of professional academic disciplines in higher educational establishments make possible to form students' knowledge and skills which are essential for independent fulfillment of all technological operations in computer-oriented environment of a preschool educational institution. Methodological developments of nursery teachers can be more efficient if they are combined with the information and communication technologies. The set of professionally oriented informatics associative connections which is the basis of informatics competencies formation may be formed as a result of the presented stages fulfillment which is based on informatics microteaching with the use of computer technologies.

We offer to consider one of the stages of future nursery teachers' professional competence formation by means of information and communications technology the creative and informational one. It involves the following tasks: analysis of pedagogical practice, development of programs and games for children, work with parents, managerial and outreach activities.

Analyzing results of pedagogical practice in preschool educational institutions it was noticed that the formation of all constituents of future nursery teachers' professional competence takes place upon condition of their interaction with preschool children.

Our research does not involve the carrying out of the in-depth analysis of the term "pedagogical readiness". The components of the mentioned readiness are specified in pedagogical literature considering its elements [7;9]. Most scientists dealing with the system of nursery teachers' professional readiness to use information and communication technologies in the educational process of preschool institution believe it includes the following components:

1) adapting and motivating;

2) planning and meaningful;

3) organizing and coordinating;

4) controlling and assessing.

The formation of future nursery teachers' professional competence based on the applying of information and communications technologies together with the use of microteaching methodology for the formation of associative connections can be assessed according to the following criteria: cognitive-informational, activityinformational, managerial-informational. Each criterion has a corresponding indicator.

Cognitive-informational criterion has the following indicators:

- students' conversance with construction, work and functions of a computer;

- the use of computer technologies by students in the process of independent studying;
- availability of presentation materials for the work with children (portfolio).

Activity-informational criterion has the following indicators:

- ability to model (design) educational situations by means of computer technologies;

- ability to model (program) and to apply developmental computer games for preschool children;

- ability to involve parents into the interaction with a preschool educational institution in the use of computer technologies for preschool children.

Information-managerial criterion has the following indicators:

- ability to use computer technologies in managerial activity of future preschool education specialists;

- ability to use PR technologies in the process of outreaching preschool educational institution's image.

\section{Conclusions}

A number of reasons of methodological, psychological and technological kind that prevents the effective implementation of information and communications technologies into the educational process of a preschool institution have been found. The absence of effective methods and technologies not only decreases the quality of the use of information and communications technologies but also forms negative attitude towards their implementation.

Regarding the task of designing programs and games, we have concluded that the use of computer technology makes lessons interesting and really contemporary. A computer, guiding a child into certain game situation and providing didactic assistance in form of educational material with illustrations and graphs, makes possible to change and improve the educational process and assessment process.

A computer increases children's motivation and fosters their interest. The innovative nature of working with a computer promotes interest to studying, and the opportunity to adjust educational tasks according to the difficulty level influences children's motivation positively.

Computer games and exercises should be regarded as a special tool that stimulates children's creative activity. They are entertaining and accessible, and the tasks in them contain not just educational material, methods and tools of its accomplishment, but also the motive and the goal which encourage children. Children, working with a computer, have a real opportunity to see the results of their activity on the screen.

Thus, computer games:

- help children to absorb educational material better, detect gaps in their knowledge and eliminate them, provide the achievement of a certain level of intellectual development by children;

- develop children's positive emotional reactions which facilitates the correction and development of psychic processes;

- stimulate children's curiosity and aspiration to achieve goals [12, p. 60-63]. 
Further research studies in this field involve determining methods regarding the use of information and

\section{ЛІТЕРАТУРА}

1. Апатова Н. В. Інституційний чинник економічного зростання / Н. В. Апатова // Вчені записки Таврійського національного університету ім. В. I. Вернадського. Серія: Економіка і управління. - 2010. - T. 23 (62). №1. - C. 22-29.

2. Бєлєнька Г. В. Формування професійної компетентності сучасного вихователя дошкільного навчального закладу [Текст] : монографія / Г. В. Бєлєнька. - К. : Київ. ун-т ім. Б. Грінченка, 2011. - 320 c.

3. Глушков В. М. Кибернетика, вычислительная техника, информатика : избранные труды в 3-х т. / В. М. Глушков. К. - : Наук. думка, 1990. - 482 с.

4. Ляшенко С. Інтеграція інформаційнокомунікаційних технологій у освітній процес / C. Ляшенко, 3. Зінченко // Вихователь-методист дошкільного закладу. - 2013. - №7. - С. 16-30.

5. Мардарова I. К. Підготовка майбутніх вихователів до використання комп'ютерних технологій в організації пізнавальної діяльності старших дошкільників: дис. ... канд. пед. наук : 13.00.08 / Ірина Костянтинівна Мардарова. - Одеса, 2012. - 239 с.

6. Новий тлумачний словник української мови.

\section{REFERENCES}

1. Apatova, N. V. (2010). Instytutsiinyi chynnyk ekonomichnoho zrostannia [Institutional factor of economic growth]. Vcheni zapysky Tavriiskoho natsionalnoho universytetu im. V.I. Vernadskoho. Seriia: Ekonomika i upravlinnia - Scientific notes of Taurida National V.I. Vernadsky University. Series "Economy and Management”, 23 (62), 1, 22-29 [in Ukrainian].

2. Bielienka, H. V. (2011). Formuvannia profesiinoi kompetentnosti suchasnoho vykhovatelia doshkilnoho navchalnoho zakladu [Formation of professional competence of modern nursery teacher of preschool educational institution]. Kyiv: Borys Grinchenko Kyiv University [in Ukrainian].

3. Hlushkov, V. M. (1990). Kibernetika, vychislitelnaya tekhnika, informatika [Cybernetics, computer technology, informatics]. Kyiv: Naukova dumka [in Russian].

4. Liashenko, S., \& Zinchenko, Z. (2013). Intehratsiia informatsiino-komunikatsiinykh tekhnolohii $\mathrm{u}$ osvitnii protses [Integration of information and communications technology into educational process]. Vykhovatelmetodyst doshkilnoho zakladu - Educationalist of preschool institution, 7, 16-30 (in Ukrainian).

5. Mardarova, I. K. (2012). Pidhotovka maibutnikh vykhovateliv do vykorystannia kompiuternykh tekhnolohii $\mathrm{v}$ orhanizatsii piznavalnoi diialnosti starshykh doshkilnykiv [Preparation of future nursery teachers for the use of computer technology in senior preschoolers' edu- communications technologies in the educational process of preschool institutions.

- У 4-х т. - т.2. - К.: «Аконт», 1999. - 901 с.

7. Панченко Алла. Модернізація освітнього процесу у ДНЗ в умовах інформатизації освіти / Алла Панченко // Вихователь-методист дошкільного закладу. -2012 - № 1. - С. 7-11.

8. Педагогика: Большая современная энциклопедия / Укл. Є. С. Рапацевич. - Мн: «Современное слово», 2005. $-720 \mathrm{c}$.

9. Смирнова-Трибульская Е. Л. Основы формирования информатических компетентностей учителей в области дистанционного обучения: монография / Е. Л. Смирнова-Трибульская. - Херсон : Айлант, 2007. $704 \mathrm{c}$.

10. Тлумачний словник української мови: понад 12500 статей (близько 40000 слів) / за ред. В. С. Калашника. - 2-ге вид., випр. і доп. - Х. : Прапор, 2005. $-992 \mathrm{c}$.

11. Чекан О. I. Застосування комп'ютерних технологій у професійній діяльності вихователя дошкільного навчального закладу: навчальний посібник / О. І. Чекан. - К. : Видавничий Дім «Слово», 2015. $184 \mathrm{c}$.

cational activity organization]. Candidate's thesis. Odesa [in Ukrainian].

6. Novyi tlumachnyi slovnyk ukrainskoi movy [New explanatory dictionary of Ukrainian language]. (1999). Kyiv: Akont [in Ukrainian].

7. Panchenko, A. (2012). Modernizatsiia osvitnoho protsesu u DNZ v umovakh informatyzatsii osvity [Modernization of educational process in preschool educational institutions under conditions of education's informatization]. Vykhovatel-metodyst doshkilnoho zakladu - Educationalist of preschool institution, 1, 7-11 [in Ukrainian].

8. Pedagogika: bolshaya sovremennaya entsiklopediya [Pedagogy: large modern encyclopedia]. (2005). Minsk: Sovremennoie slovo [in Russian].

9. Smirnova-Tribulskaya, E. L. (2007). Osnovy formirovaniya informaticheskikh kompetentnostei uchitelei $v$ oblasti distantsionnogo obucheniya [Basis of formation of informatics competencies of teachers in the field of distance learning]. Kherson: Ailant [in Russian].

10. Kalashnyk, V.S. (Ed.). (2005). Tlumachnyi slovnyk ukrainskoi movy [Explanatory dictionary of the Ukrainian language]. Kharkiv: Prapor [in Ukrainian].

11. Chekan, O. I. (2015). Zastosuvannia kompiuternykh tekhnolohii u profesiinii diialnosti vykhovatelia doshkilnoho navchalnoho zakladu [The use of computer technology in professional activity of educator of preschool educational institution]. Kyiv: Slovo [in Ukrainian]. 
Оксана Іванівна Чекан, кандидат педагогічних наук, старший викладач, Христина Василівна Барна, кандидат педагогічних наук, старший викладач, Вікторія Вікторівна Іванова, кандидат психологічних наук, старший викладач, кафедра теорії і методики дошкільної освіти, Мукачівський державний університет, вул. Ужггородська, 26, м. Мукачево, Украӥна

\section{ФОРМУВАННЯ ПРОФЕСІЙНОЇ КОМПЕТЕНТНОСТІ МАЙБУТНІХ ВИХОВАТЕЛІВ ЗАСОБАМИ ІНФОРМАЦЙНО- КОМУНІКАЦЙНИХ ТЕХНОЛОГІЙ}

Ми живемо у вік інформації, коли відбувається комп’ютерна революція. Ми є свідками того, що комп'ютери вже зайняли міцні позиції в багатьох галузях сучасного життя. Вони швидко проникають і у дошкільні навчальні заклади. Проблема формування професійної компетентності майбутніх вихователів засобами інформаційно-комунікаційних технологій стала особливо актуальною в наші дні. Сучасний рівень розвитку суспільства вимагає освічених фахівців, людей творчих, здатних до вільного мислення. Метою статті є аналіз етапів формування професійної компетентності майбутніх вихователів дітей дошкільного віку засобами інформаційно-комунікаційних технологій. У статті також проаналізовано психолого-педагогічну літературу щодо сутності поняття «інформаційно-комунікаційні технології». Уточнено основні етапи формування професійної компетентності вихователя. Розкрито компоненти (адаптивно-мотиваційний; планово-змістовний; організаційно-координаційний; контролювально-оцінний) щодо формування професійної компетентності майбутніх вихователів дітей дошкільного віку. Визначено компоненти з використанням методик мікровикладання для формування асоціативних зв'язків у майбутніх фахівців дошкільної освіти. Конкретизовано елементи готовності відповідно до визначених нами їі компонентів. Виявлено ряд причин методичного, психологічного та технологічного характеру, що заважають ефективному впровадженню інформаційно-комунікаційних технологій у навчально-виховний процес дитячого закладу. Проаналізовано подані нами етапи формування професійної компетентності майбутніх вихователів дітей дошкільного віку засобами інформаційно-комунікаційних технологій. Розглянуто один із етапів щодо формування професійної компетентності майбутніх вихователів дітей дошкільного віку засобами інформаційно-комунікаційних технологій - креативно-інформаційний. Обгрунтовано завдання цього етапу (аналіз педагогічної практики, проектування програм та ігор для дітей, робота з батьками, управлінська та пропагандистська роботи). Виведено критерії (когнітивно-інформаційний, діяльнісноінформаційний та інформаційно-управлінський) й показники (обізнаність студентів із будовою, роботою і функціями комп'ютера; використання студентами КТ у самостійній навчальній діяльності; наявність презентаційних матеріалів для роботи з дітьми (портфоліо); вміння моделювати (проектувати) навчальні ситуації засобами КТ; вміння моделювати (програмувати) і застосовувати комп'ютерні розвивальні ігри для дітей дошкільного віку; вміння залучати батьків для спільної роботи з ДНЗ у використанні КТ для дітей дошкільного віку; вміння використовувати КТ в управлінській діяльності майбутніх фахівців дошкільної освіти; вміння використовувати PR (технології) у процесі пропаганди іміджу ДНЗ) формуванні професійної компетентності майбутніх вихователів дітей дошкільного віку засобами інформаційно-комунікаційних технологій.

Ключові слова: інформаційно-комунікаційні технології, професійна компетентність, комп'ютерноорієнтовані технології.

Submitted on March, 20, 2017

Reviewed by Doctor of Pedagogy, prof. H. Tovkanets 